\title{
Strategies for Better Learning of English Grammar: Chinese vs. Thais
}

\author{
Patnarin Supakorn ${ }^{1}$, Min Feng ${ }^{1} \&$ Wanida Limmun ${ }^{2}$ \\ ${ }^{1}$ School of Liberal Arts, Walailak University, Nakhon Si Thammarat, Thailand \\ ${ }^{2}$ School of Science, Walailak University, Nakhon Si Thammarat, Thailand \\ Correspondence: Patnarin Supakorn, School of Liberal Arts, Walailak University, Nakhon Si Thammarat, 80161, \\ Thailand. Tel: 66-82-455-6659. E-mail: patnarintra@gmail.com
}

Received: November 1, 2017 Accepted: February 11, 2018 Online Published: February 13, 2018

doi: 10.5539/elt.v11n3p24 URL: http://doi.org/10.5539/elt.v11n3p24

\begin{abstract}
The success of language learning significantly depends on multiple sets of complex factors; among these are language-learning strategies of which learners in different countries may show different preferences. Needed areas of language learning strategy research include, among others, the strategy of grammar learning and the context-based approach to learning strategies. To fill in these gaps, this study aimed at finding the grammar learning strategies adopted by high school students as well as exploring the national differences between Chinese and Thai students. The results showed that in general the strategies significantly taken up by the high achievers in the grammar test included the metacognitive, the memory, the social and the cognitive. In terms of the national differences, the strategies that characterized the Thai students were the social and the affective. Regarding the Chinese, even though they generally applied all strategy categories at lower frequencies, they were found to prefer different sub-strategies in the following three categories: memory (revision and space reliance), cognitive (note taking) and metacognitive (lesson preview). The findings lead to implications for learners of grammar, interesting future research in grammar strategies and culturally responsive grammar teaching.
\end{abstract}

Keywords: Chinese, grammar, learning strategy, Thai

\section{Introduction}

In the English education, due to individual differences, some learners acquire a new language more quickly and effectively, while others may struggle and make slow progress (Dörnyei \& Skehan, 2003; Lightbown \& Spada, 1999; Vance, 1999; Robinson, 2002). One of the factors attributing to individual differences is the learning strategies (Ellis, 2004; Ehrman, Leaver, \& Oxford, 2003) which, according to Oxford (1990: 8), refer to specific actions taken by the learner to make learning easier, faster, more enjoyable, more self-directed, more effective, and more transferable to new situations. Using learning strategies consciously would help learners learn English more quickly and effectively (Rubin, 1975). There is a consensus in the study of learning strategies; proficient L2 learners have a wider repertoire of strategies and draw on them to accomplish L2 tasks (Chamot, 2004; Oxford, 2001; Pawlak (2009). This study aims to investigate two needed areas in the learning strategy research, grammar learning strategies and cultural influences. The literature review below covers the significance of the theory of learning strategies in the second language acquisition (SLA), needed areas of learning strategy research, the significance of grammar in the EFL context and studies on grammar strategies.

\section{Literature Review}

\subsection{Significance of Learning Strategies in SLA}

Since learning strategies, which can be taught (Oxford ,1990; Vance, 1999), play such a crucial role in language acquisition, exploring language learning strategies used by successful learners and teaching them to unsuccessful learners can help the latter enhance their second or foreign language learning (Rubin, 1975). Scholars believe that strategy instruction is most effective when it is integrated into regular classroom instruction (Cohen, 1998; Oxford \& Leaver, 1996; Anderson, 2005). Nunan (1996: 41), for example, has suggested language classrooms should have a dual focus, not only on teaching language content but also on developing learning processes as well. Cohen (2011: 683) states interest in enhancing the learning and use of an L2 through strategy instruction has been on the rise at the elementary- and secondary-school and university levels, at adult centers, as well as in self-access centers (See also Rubin, Chamot, Harris, \& Anderson, 2007; Chamot, 2008). Indeed, a number of past studies have also attested the benefits of the integration of the strategy instruction in all language skills: 
listening (O’Malley \& Chamot, 1990; Goh, 1997; Vandergrift, 1997, 1999, 2002; Harris \& Grenfell, 2008), reading (Zhang, 2008), speaking (Cohen, Weaver, \& Li, 1997; Iwai, 2006), writing (Huang, 2007), vocabulary (Chan, 2005), grammar (Morales \& Smith, 2008a, 2008b; Cohen, Pinilla-Herrera, Thompson, \& Witzig, 2011), and pragmatics (Cohen, 2008; Sykes \& Cohen, 2008, 2009).

In terms of grammar learning, scholars propose that the teaching should go beyond the grammatical contents to the process of learning grammatical points (Sharwood Smith, 1993; Ellis, 2002). Larsen-Freeman (2001, 2003) emphasizes the significance of the grammar learning skill development; she proposes it is better to think of teaching the fifth skill area of 'grammaring,' rather than 'grammar.'

\subsection{Needed Areas in Learning Strategy Research}

According to Cohen (2011: 695) language learner strategies have played highly varied roles in research and there is still much to do. Recommended further work includes the investigation of grammar strategies and the context-based approach to learners' strategy use.

Although language learning strategy research has become more and more popular in the L2 field since 1970s, learning strategy researchers have not given as much attention to the grammar acquisition as to the other language skills (Anderson, 2005, Pawlak, 2009). Cohen (2011: 689) cited a position paper by Oxford, Lee and Park (2007) on how grammar strategies had largely been ignored in the research literature. Cohen asserts much attention has been on the teaching of grammar, but not so much on how learners learn grammar (690) and concludes that grammar learning strategies are one of the needed work in domains of strategy use (695). Oxford et al. specifically propose collaborative, interdisciplinary research on grammar strategies which they believe will benefit learners everywhere and facilitate the work of L2 teachers and help promote the understanding of how people learn another language (137).

Anderson further proposes that L2 strategy research should also explore the application of L2 strategies in different learning environments (768). In this regards, Griffith (2010: 5) mentions that individuals do not exist in isolation; they are born into a particular nationality/ethnicity/culture and throughout their lives, this very environment will exert an influence on language learning in one way or another.

In order to fill in this gap, this study investigated not only the good learners' grammar learning strategies but also the Chinese's and the Thais' application of grammar learning strategies.

\subsection{Significance of Grammar in EFL Contexts}

Rubin's (1975) has emphasized the significance of grammar knowledge to the success among good language learners. In language education, a number of scholars refer to grammar as the heart, the core or the frame of language learning (Purpura, 2004; Saaristo, 2015). Wang (2010), for example, states grammar is just like a frame of house; without this framework, good materials and building blocks cannot constitute a solid house. Batstone (1994) states as the learner's distance to the target language grows, like in the context where English is used as a foreign language, grammar becomes more useful; it helps learners be able to shape the order and organization of information more effectively. Duso (2007), cited by Pontarolo (2013), argues that the issue is not whether grammar should be taught but how it can be applied to the foreign language teaching. The results from this study, therefore, help shed some light on useful grammar learning strategies that should be included in the grammar class.

From the learner's perspective, McDonough (2002), who investigated what facilitates the learning of a foreign language, found that $81 \%$ of the learners in the study valued the usefulness of grammar practice. Bade (2008) similarly argues that the formal grammar instruction is not only welcomed but in fact demanded by students; the only condition expressed by learners is that grammar teaching should not take precedence over other aspects of language teaching. A successful language learner in Griffiths' study (2010: 13) further reported in an interview that along with many other practices, he spent two to three hours a day working on his grammar. A study carried out by Farjami (2011) also confirms learners' interest in studying grammar because it helps promote their development of language proficiency and language skills.

\subsection{Studies on Grammar Strategies}

Foci of past studies on grammar strategies can be classified into 4 categories: the identification of learners' strategies, the relationship between individual differences and the strategy application, the effect of strategy integration in grammar instruction and the relationship between strategy application and achievement.

Attempting to identify good learners' grammar strategies, Fortune (1992) found that the higher level the learners were, the more likely they preferred inductive grammar exercises. Pawlak's study (2008) showed that advanced 
Polish EFL learners, employing varied grammar learning strategies but failing to apply grammar structures in communicative tasks, preferred traditional strategies. Bade (2008) reported, based on a study of a 20 -week course entitled "English for Living and Working in New Zealand," the following grammar strategies: using time outside of class to practice each grammar point for 10 minutes, trying out grammar forms in their own sentences based on a model sentence, and basing their learning of a grammar point on explicit rules and a text that exemplifies these rules so that they could learn the points accurately. Morales and Smith (2008a) reported highly-motivated students of Spanish used strategies involving mental images in order to remember the correct use of grammatical forms.

Regarding the relationship between learner differences and strategy application, Anderson (2005: 759) mentions more research is needed on the influence of individual differences and language learning. Bayou (2015), who studied the influence of gender on grammar learning strategies applied by grade 11 students, provides a sample study in this needed area. However, it was found that there was no significant relationship between gender and grammar strategy application.

There were also studies on the effectiveness of strategy instruction in grammar learning. Morales and Smith (2008b) showed that 113 American university students of Spanish with brief exposure to visual images associated with the uses of ser and estar showed a greater improvement in their ability to distinguish the correct use of each verb than did the 90 students in the control group who did not get exposure to visual images to help in learning the distinction. Cohen, Pinilla-Herrera, Thompson, and Witzig (2011) similarly found that learners of Spanish grammar, having been exposed to over 70 grammar strategies on a website suggested by successful learners, benefited greatly from the use of the website.

Another group of scholars investigated the relationship between the grammar strategy application and learning achievement. Some reported a negative correlation between the two factors (Tilfarlioğlu, 2005; Pawlak, 2009); others reported a positive relation (Mystkowska-Wiertelak, 2008).

\section{Method}

\subsection{Research Questions}

In order to fill in the gap of research in grammar strategies and the need for the context-based approach to the field of learning strategy, the present study aims at answering the following 4 questions:

(1) What strategies do the higher and lower achievement learners apply in their English grammar learning?

(2) Do the Chinese and the Thai higher achievement learners apply the grammar learning strategies similarly or differently?

(3) Do the Chinese and the Thai lower achievement learners apply the grammar learning strategies similarly or differently?

(4) Are there any strategies that typically distinguish Chinese from Thais?

\subsection{Subjects}

The subjects in the study were 168 grade 11 students: 91 Chinese and 77 Thais. The subjects were grouped into three proficiency levels: higher, intermediate and lower. However, this study focused only on the higher and lower achievers' grammar learning strategies.

\subsection{Instruments}

Two research instruments, as detailed below, are a grammar proficiency test and a questionnaire on grammar learning strategies.

In order to categorize the subjects into higher, intermediate and lower achievement learners, the researchers developed a 60-item grammar proficiency test, covering those basic aspects required for the formation of sentences in English: the use of the noun and the pronoun in the subject, the use of finite verb forms in the predicate, the use of the non-finite verb forms, the use of the modifiers, the use of connectives, and the use of the punctuation marks and capitalization. The test lasted for 60 minutes, so the average time for each item was one minute. In order to ensure the reliability and the validity of the test, the researcher had piloted it with a group of 49 Chinese and 43 Thai grade 11 students who were studying at other high schools. The Cronbach's alpha reliability of the test was 0.753 .

The questionnaire in this study consisted of two parts. Part 1 contained questions eliciting the participant's background information (e.g., gender, nationality). Part 2 was a 30-item grammar learning strategy questionnaire based on Oxford's (1990) Strategy Inventory for Language Learning (SILL), covering the following six parts: 
the memory category, the cognitive category, the compensation category, the metacognitive category, the affective category and the social category. The subjects answered each item by rating on a 5-point Likert-scale, ranging from 1 (never or almost never true of me) to 5 (always or almost always true of me).

In order to avoid any misunderstandings and ensure the result accuracy, the questionnaire had been translated into Chinese and Thai for the Chinese and the Thai subjects respectively. The Thai translation was done by the main correspondent of the study, a native Thai and the Chinese translation by a native Chinese co-researcher. The two versions of the questionnaire were piloted to the similar groups of 49 Chinese and 43 Thai grade 11 students who took the piloted grammar test. The Cronbach's alpha reliability of the Chinese version was 0.848 , and the Thai version was 0.899 .

\section{Results}

\subsection{Analysis}

Based on the grammar test scores, the 168 subjects were first categorized into three groups: 47 higher achievers $(65-100 \%), 58$ intermediate achievers $(50-64 \%)$ and 63 lower achievers $(0-49 \%)$. The study specifically focused on the higher and the lower achievers.

Next, to investigate the application of the grammar learning strategies between the higher and the lower achievers, the means scores of the overall strategy use and of each of the six strategy categories were calculated, adapted from Oxford's SILL average analysis (1990), displayed below.

\begin{tabular}{lll}
\hline Frequency & Range of Means & Interpretation \\
\hline Uppermost high & $4.5-5.0$ & always or almost always used \\
High & $3.5-4.4$ & often used \\
Upper medium & $3.1-3.4$ & sometimes used \\
Lower medium & $2.5-3$ & \\
Low & $1.5-2.4$ & seldom used \\
Lowermost & $1.0-1.4$ & never or almost never used \\
\hline
\end{tabular}

In order to learn the differences between the higher and the lower achievers as well as between the Thais and the Chinese, the independent sample T-test was run to find out the strategy categories that were applied significantly differently. The .05 level of statistical significance was set at all statistical tests in the study. Then, in order to prioritize the strategy categories with the significant difference, the degree of the means difference of each of the six strategy categories was calculated. Specifically, the independent sample T-test was first applied to find out the strategies categories that strongly differentiated the focused groups of comparison and the degree of means difference was next applied to rank the strategy categories with the strongest power of the differentiation to the lower ones.

Finally, to identify learning strategies that differentiated the Thais from the Chinese, the sub-strategies of the categories of significant difference were further compared.

\subsection{Findings}

\subsubsection{Higher vs. Lower Achievers' Learning Strategies}

Table 1 shows that the higher achievers applied the grammar learning strategies significantly more frequently than the lower achievers both in terms of the overall strategy use and of each of the six strategy categories.

Regarding the ranking of the six strategy categories, both the higher and the lower achievers applied the compensation strategy category most frequently. This might be because both Chinese and Thai students are learners of English as a foreign language, for whom guessing is a natural part of the acquisition of foreign languages. This finding was in line with many past studies (Sun, Mantero \& Summers, 2014) which revealed that compensation strategies were the most frequently used among the six strategy categories. According to Oxford (1990: 47), compensation strategies, one of the most important strategy categories for beginning and intermediate language learners, enable learners to use the language for either comprehension or production despite limitations in knowledge of grammar and, especially, of vocabulary. 
Table 1. Grammar learning strategies of the higher and the lower achievers

\begin{tabular}{llllllllll}
\hline \multirow{2}{*}{ Rank } & Strategy & \multicolumn{2}{l}{ Higher achievers } & \multicolumn{2}{l}{ Lower achievers } & & & \\
\cline { 2 - 5 } & categories & Means & SD & Means & SD & t & df & P-value \\
\hline 1 & Compensation & 3.44 & .47 & 2.95 & .31 & 4.786 & 108 & $.000^{*}$ \\
2 & Metacognitive & 3.35 & .31 & 2.68 & .23 & 4.650 & 108 & $.000^{*}$ \\
3 & Memory & 3.25 & .07 & 2.6 & .18 & 2.778 & 108 & $.000^{*}$ \\
4 & Cognitive & 3.24 & .39 & 2.66 & .50 & 4.879 & 108 & $.000^{*}$ \\
5 & Social & 3.23 & .44 & 2.59 & .33 & 3.559 & 108 & $.000^{*}$ \\
6 & Affective & 2.97 & .60 & 2.45 & .39 & 4.282 & 108 & $.000^{*}$ \\
& Overall & 3.25 & .16 & 2.65 & .17 & 5.278 & 108 & $.000^{*}$ \\
\hline
\end{tabular}

$* \mathrm{p}<0.05$.

However, in order to learn characteristics that distinguish the good learners from the weak ones, it is necessary to find out the differences in the application of the grammar learning strategies through the comparison of the means difference which is displayed in the bar graph below.

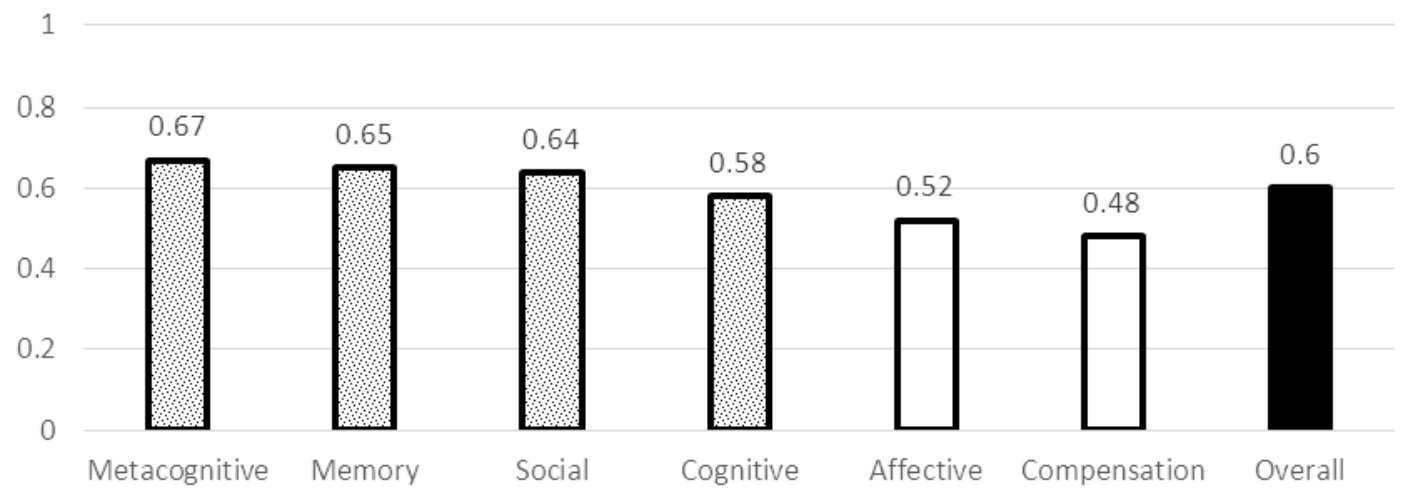

Figure 1. Means differences - Higher vs. lower achievers

Figure 1 shows that the order of the six strategy categories based on the means difference values from the greatest to the smallest is the metacognitive strategies $(0.67)$, the memory strategies $(0.65)$, the social strategies $(0.64)$, the cognitive strategies $(0.58)$, the affective strategies $(0.52)$ and the compensation strategies $(0.48)$. The greatest difference between the higher and the lower achievers lies in the use of the metacognitive strategies and the smallest difference lies in the use of the compensation strategies. The greater the means difference a strategy category shows, the better indicator it is to distinguish the higher achievers from the lower achievers. Based on the figure above, the following four categories including the metacognitive, the memory, the social, and the cognitive should be better indicators for better learners than the affective and the compensation.

In conclusion, even though the independent sample T-test, as displayed in Table 1, shows that the higher achievers applied all of the six strategy categories significantly more frequently than the lower achievers. The comparison of the means differences of the six strategy categories between the higher achievers and the lower achievers reveals that the strategy categories that better distinguished the higher achievers from the lower achievers in this study should be those with the means difference greater than 0.5 , including the metacognitive, the memory, the social and the cognitive.

The fact that the application of the metacognitive strategies category was the one with the greatest difference between the higher and the lower achievers in this study supports Anderson's hypothesis on a hierarchy of language learning strategies (2005: 766); Anderson believes that the metacognitive strategies play a more significant role because once a learner understands how to regulate his or her own learning through the use of strategies, language acquisition should proceed at a faster rate. Similarly, Cohen (2011: 683) states good learners 
use a variety of strategies to accomplish what they accomplish, especially metacognitive ones. The significant role of the metacognitive strategies on the success of L2 learning is supported by a number of scholars (Anderson, 2008, O’Malley \& Chamot, 1990, Skehan, 1989, Vandergrift, 2002, Vann \& Abraham, 1990 and Wenden, 1998). Likewise, Griffiths (2010: 8), in her qualitative study of two successful language learners, found that one of her subjects opted so emphatically for the group of strategies related to the ability to manage the learning process, which many writers consider typical of successful learners; the other one took a lot of initiatives in her English study.

\subsubsection{Chinese vs. Thai Higher Achievers}

Table 2. Grammar learning strategies of Chinese and Thai higher achievers

\begin{tabular}{llllllll}
\hline $\begin{array}{l}\text { Strategy } \\
\text { categories }\end{array}$ & Higher Chinese & \multicolumn{7}{l}{ Higher Thais } \\
Means & SD & Means & SD & t & df & P-value \\
\hline Memory & 2.80 & .48 & 3.39 & .17 & 2.026 & 44 & $.049^{*}$ \\
Cognitive & 2.71 & .75 & 3.40 & .34 & 2.697 & 44 & $.010^{*}$ \\
Compensation & 3.00 & .51 & 3.57 & .45 & 1.380 & 44 & .175 \\
Metacognitive & 3.02 & .20 & 3.45 & .38 & 1.090 & 44 & .282 \\
Affective & 2.42 & .41 & 3.14 & .66 & 2.399 & 44 & $.021^{*}$ \\
Social & 2.62 & .37 & 3.42 & .47 & 2.549 & 44 & $.041^{*}$ \\
Overall & 2.76 & .23 & 3.40 & .16 & 3.505 & 45 & $.010^{*}$ \\
\hline
\end{tabular}

$* \mathrm{p}<0.05$.

Table 2 shows that the Thai higher achievers applied the grammar-learning strategies more frequently than the Chinese higher achievers both in terms of the overall strategy application and in terms of each of the six strategy categories. However, there were significant differences in the use of memory, cognitive, affective, and social strategies.

A further analysis with the means difference, as displayed in the bar graph below, showed that among the four strategy categories with the significant difference, the social category displayed the greatest gap between the high Thais and Chinese, followed by the affective, the cognitive and the memory categories.

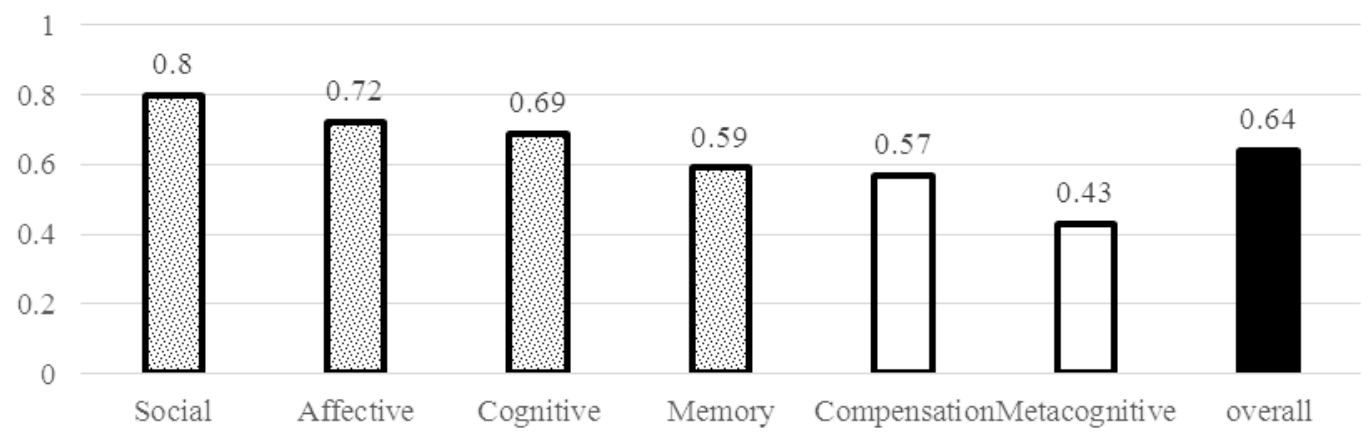

Figure 2. Means differences - Thai and Chinese higher achievers

In conclusion, the analysis shows that the higher Thais differed from the higher Chinese in the following four categories ordered from the one with the greatest means difference to the lower: the social, the affective, the cognitive and the memory.

\subsubsection{Chinese vs. Thai Lower Achievers}

Table 3 above shows that, similar to what was found among the higher achievers, the Thai lower achievers applied all categories of the grammar learning strategies at a higher frequency than the Chinese counterparts.

The independent t-test revealed that overall the lower Thais applied the grammar-learning strategies significantly 
more frequently than the Chinese counterparts. In term of each of the six strategy categories, significant differences were found in the use of the metacognitive, social and affective categories.

Table 3. Grammar learning strategies of Chinese and Thai lower achievers

\begin{tabular}{llllllll}
\hline $\begin{array}{l}\text { Strategy } \\
\text { categories }\end{array}$ & \multicolumn{2}{l}{ Lower Chinese } & \multicolumn{2}{l}{ Lower Thai } \\
Means & SD & Means & SD & $\mathrm{t}$ & $\mathrm{df}$ & P-value \\
\hline Compensation & 2.87 & .32 & 3.29 & .29 & 1.287 & 60 & .203 \\
Cognitive & 2.61 & .60 & 2.87 & .30 & 1.162 & 60 & .250 \\
Metacognitive & 2.58 & .19 & 3.10 & .46 & 2.219 & 60 & $.030^{*}$ \\
Social & 2.56 & .38 & 3.15 & .33 & 2.980 & 60 & $.004^{*}$ \\
Memory & 2.52 & .19 & 2.93 & .23 & 1.702 & 60 & .094 \\
Affective & 2.33 & .31 & 2.95 & .73 & 2.568 & 60 & $.013^{*}$ \\
Overall & 2.56 & .18 & 3.05 & .18 & 2.751 & 61 & $.008^{*}$ \\
\hline
\end{tabular}

$* \mathrm{p}<0.05$.

To further check the degree of the difference of each of the six strategy categories, the means difference was analyzed, showing that, as displayed in Figure 3, the strategy categories with the means difference greater than 0.5 were the affective, the social and the metacognitive. These three strategy categories with the great means differences matched those three analyzed through the independent t-test.

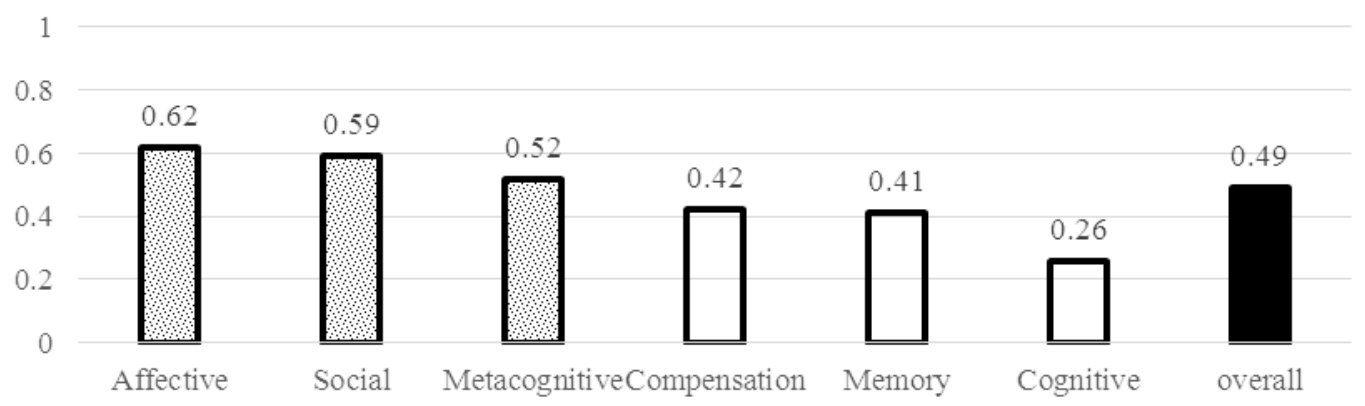

Figure 3. Means differences - Thai and Chinese lower achievers

In conclusion, the comparison of the lower achievers shows that the Thai lower achievers applied the following three strategy categories at a higher frequency than the Chinese lower achievers: the affective, the social and the metacognitive.

\subsubsection{Chinese's vs. Thais' Learning Strategies}

In order to find out the characteristics that distinguished the Thai learners from the Chinese, the investigation attempted to uncover features that only the higher and the lower Thais similarly shared but not the Chinese as well as only those that the higher and lower Chinese similarly adopted but not the Thais.

In this section, the application of the sub-strategies under all of the strategy categories of significant difference was further analyzed to learn more about the differences between the Thais and the Chinese.The analyses in (4.2.2) and (4.2.3) show that the strategy categories that strongly differentiated the higher Thais from the higher Chinese were the social, the affective, the cognitive and the memory and those that strongly differentiated the lower Thais from the lower Chinese were the affective, the social and the metacognitive. Therefore, the social and the affective strategy categories, which were applied at a significantly higher frequency by both the higher and lower Thais than the Chinese, were the ones that characterized the Thai students. The order of the analysis starts from the two strategy categories: the social and the affective, which the Thais students applied significantly more frequently than the Chinese students. Then, the analysis continued with the application of the sub-strategies of the other two strategy categories that significantly differentiated the higher Thais from the higher Chinese: the 
cognitive and the memory. Finally, the investigation ended with the other strategy category that significantly differentiated the lower Thais from the lower Chinese: the metacognitive.

As displayed in Figures 4 and 5, a comparison of the difference of the means of the social sub-strategies shows that both the higher and lower Thais similarly applied two social sub-strategies at a highly greater frequency than the Chinese; the means difference of these two social sub-strategies was $\geq 0.7$ : the social sub-strategy \#30 (asking teachers for learning methods) and the social sub-strategy \#29 (consulting better learners).

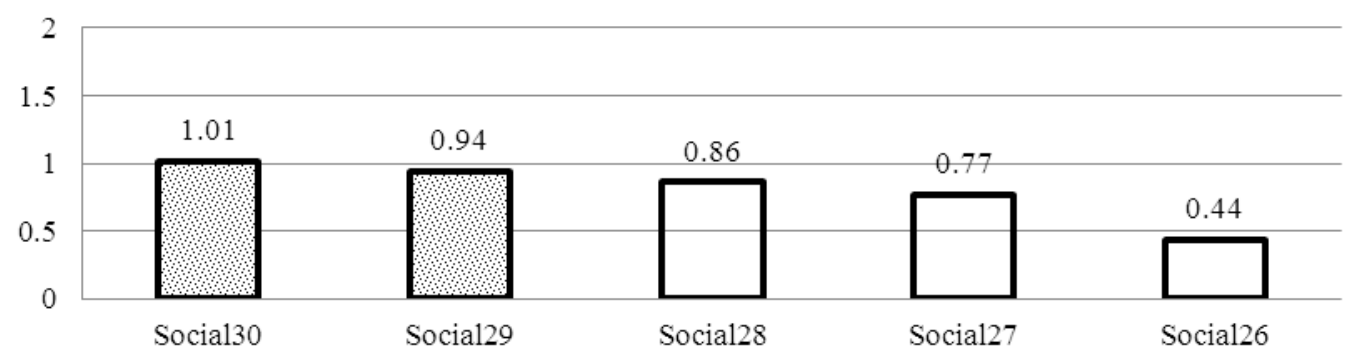

Figure 4. Means difference of social sub-strategy - Higher Thais vs. Higher Chinese

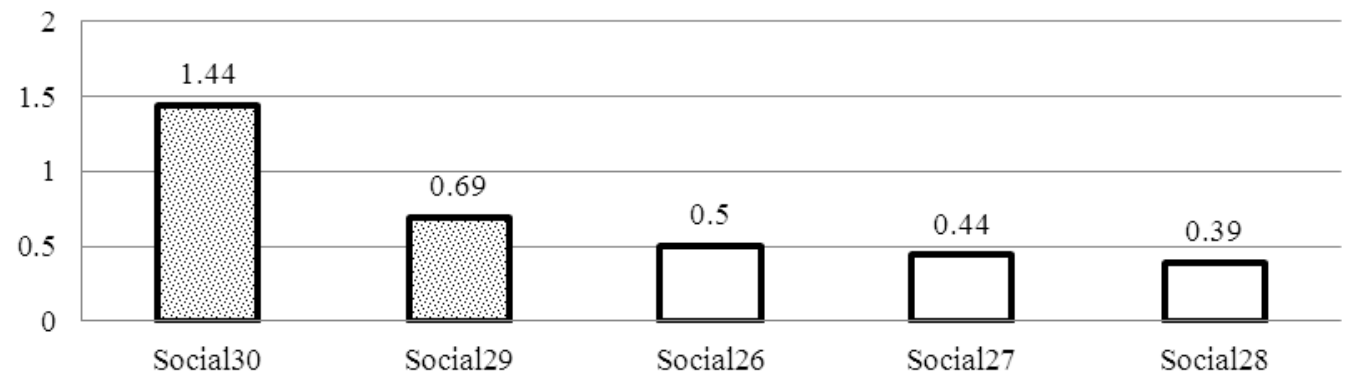

Figure 5. Means comparison of social sub-strategies - Lower Thais vs. Chinese

Based on the means difference comparison, the social sub-strategies that characterized the Thais were their significantly higher tendency to consult teachers and better learners to improve their grammar learning methods.

The comparison of the means of the application of the affective sub-strategies showed that both the higher and lower Thais applied all of the affective sub-strategies at a higher frequency than the Chinese. However, both the higher and lower Thai achievers applied two affective sub-strategies with the means difference close to 1 and over: the affective sub-strategy \#25 (self-encouragement) and the affective sub-strategy \#21 (relaxation).

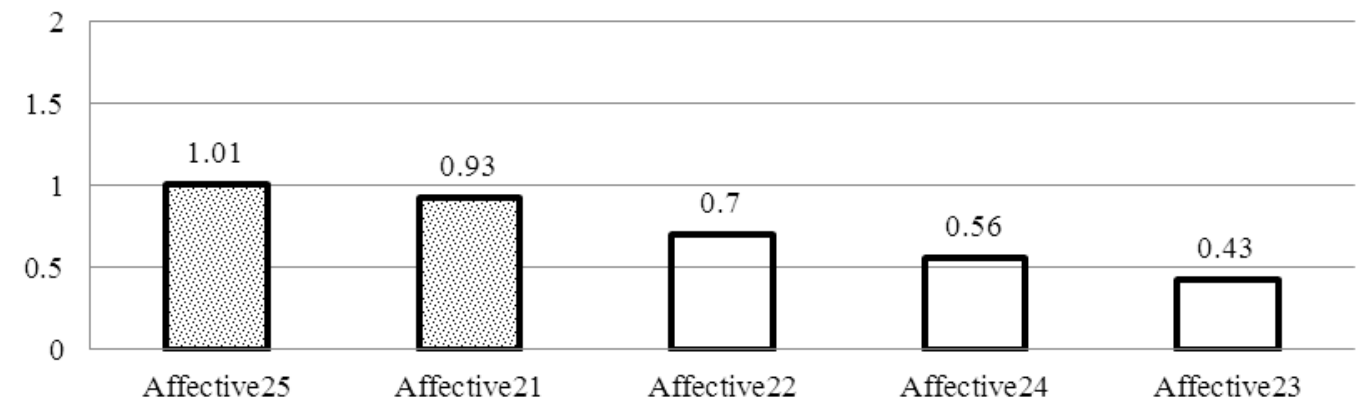

Figure 6. Means differences of affective sub-strategies - Higher Thais vs. Chinese 


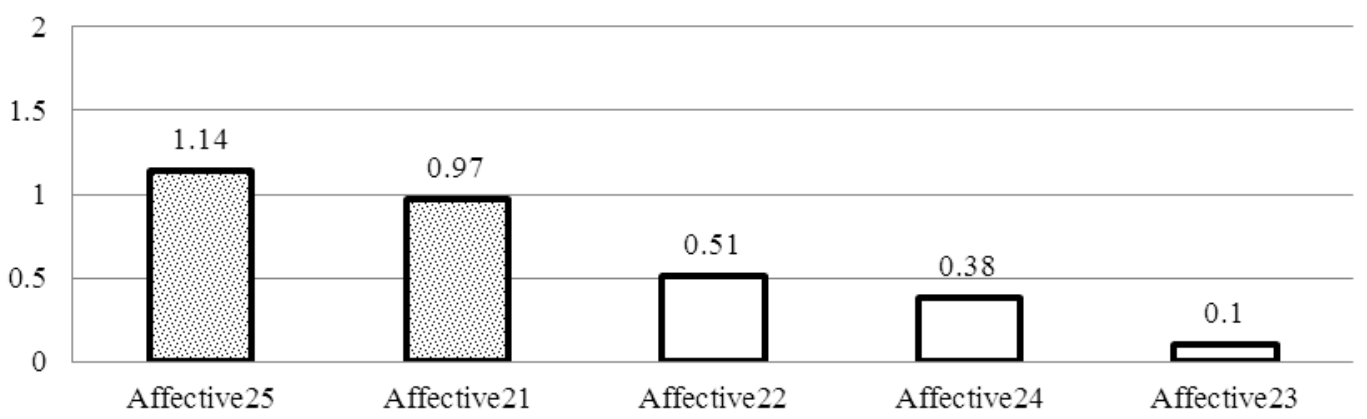

Figure 7. Means difference of affective sub-strategies - Lower Thais vs. Chinese

Therefore, the Thai students were significantly better than the Chinese to deal with their negative feeling of learning grammar; furthermore, they relatively had a higher level of self-encouragement and of emotional management.

Earlier, as displayed in Table 2 above, the independent sample T-test showed that in comparison to the higher Chinese, the higher Thais were better users of the cognitive strategy category. A further comparison of the difference of the means of the cognitive sub-strategies, applied by the higher Thais/Chinese and by the lower Thais/Chinese, showed a similarity shared by the Thais and by the Chinese. The former, both the higher and lower achievers, applied the cognitive sub-strategy \#10 (using tables to learn grammar) much more frequently than the latter (The means difference was around 1 for both higher and lower Thais). The Chinese, on the other hand, both the higher and the lower Chinese, applied the cognitive sub-strategy \#9 (note taking) more frequently than the Thais.

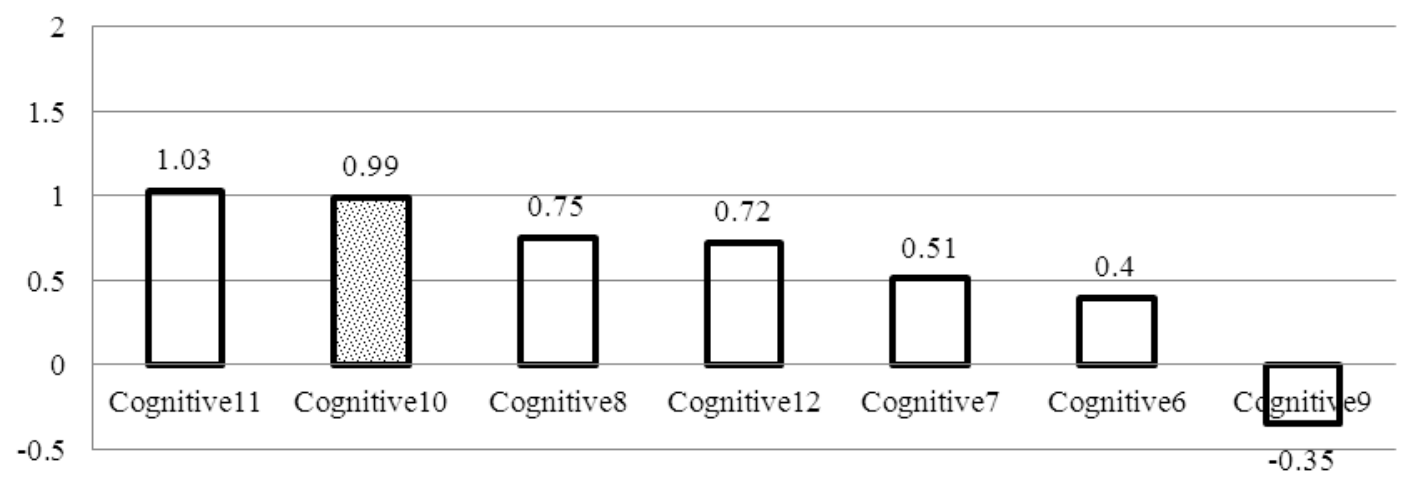

Figure 8. Means differences of cognitive sub-strategies - Higher Thais vs. Chinese

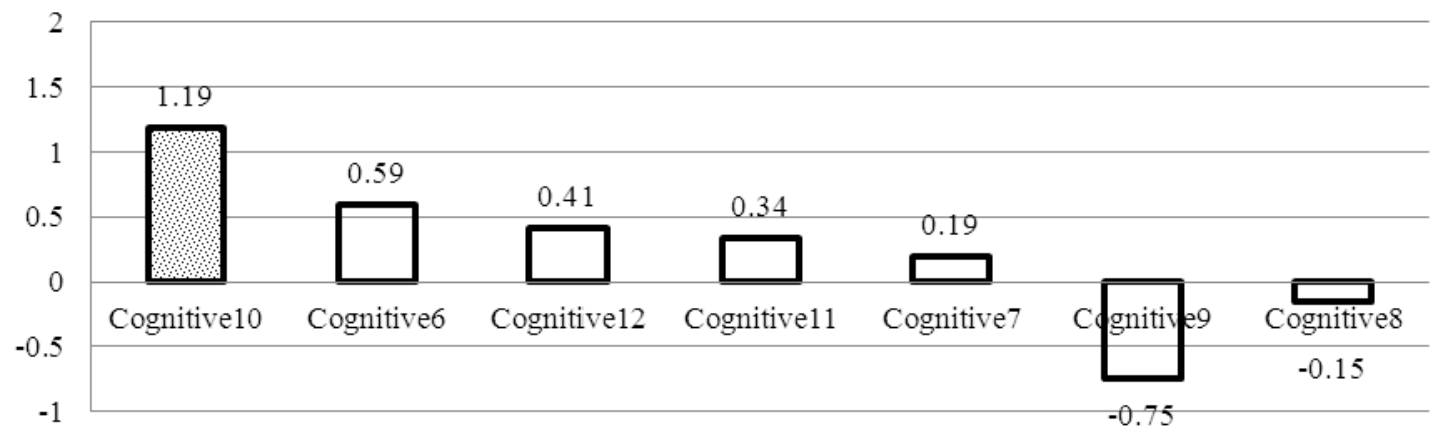

Figure 9. Means differences of cognitive sub-strategies - Lower Thais vs. Chinese

The comparison of the difference of the means of the cognitive sub-strategies, therefore, showed that the Thais 
relied significantly more on the use of tables to enhance their grammar knowledge; however, the Chinese preferred note taking.

The memory strategy category was the other one that significantly differentiated the higher Thais from the higher Chinese. The comparison of the difference of the means of the memory sub-strategies applied by the higher Thais vs. the higher Chinese and the lower Thais vs. the lower Chinese, showed that both the higher and lower Thais were better users of the memory sub-strategy \#1 (mind-mapping) than the Chinese; the means difference of the memory sub-strategy $\# 1$ was around 0.7 .

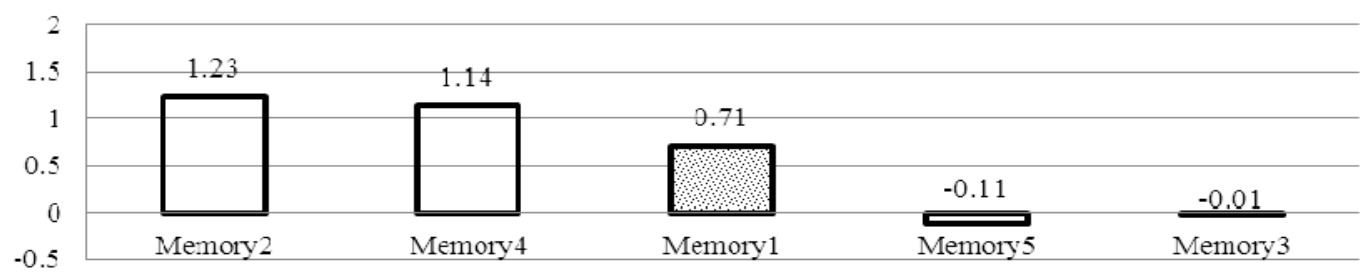

Figure 10. Means difference of memory sub-strategies - Higher Thais vs. Chinese

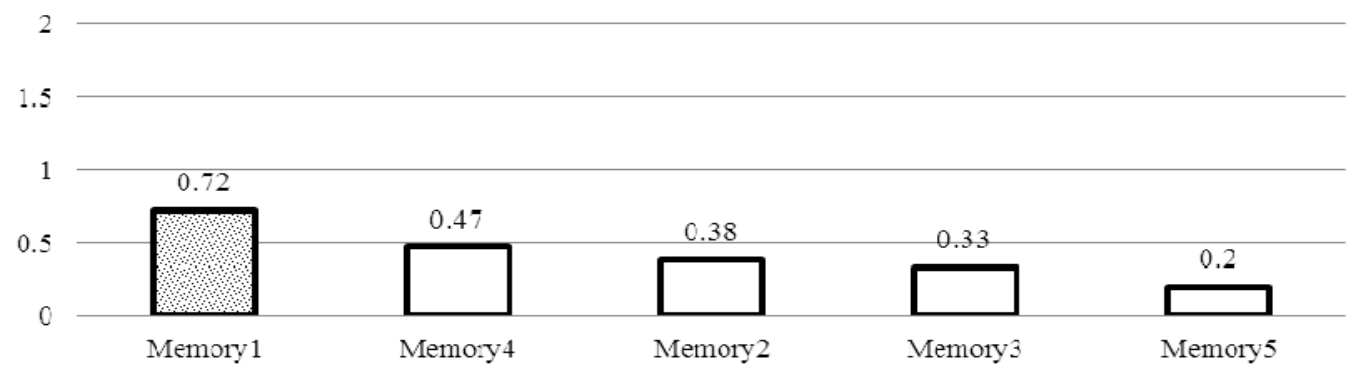

Figure 11. Means difference of memory sub-strategies - Lower Thais vs. Chinese

However, for the memory strategy category, a further comparison of the means ranking, as displayed in Table 4 and Table 5, revealed an interesting cultural preference. While both the higher and lower Chinese placed the memory sub-strategy \#5 (revision) at the top application frequency, the Thais, both the higher and lower achievers, placed it toward the least application frequency. In fact, the latter preferred the memory sub-strategy \#1 (mind mapping) and the memory sub-strategy \# 4 (mental images).

Table 4. Memory strategies - Chinese high achievers vs. Thai high achievers

\begin{tabular}{|c|c|c|c|c|}
\hline \multirow{3}{*}{$\begin{array}{l}\text { Order of } \\
\text { strategies }\end{array}$} & \multirow[b]{3}{*}{ Description } & \multicolumn{2}{|l|}{ High } & \multirow{2}{*}{$\begin{array}{l}\text { High } \\
\text { Thais }\end{array}$} \\
\hline & & Chinese & \multirow{2}{*}{$\begin{array}{l}\text { Order of } \\
\text { strategies }\end{array}$} & \\
\hline & & Means & & Means \\
\hline Memory5 & $\begin{array}{l}\text { I review the grammar rules and structures very } \\
\text { often. }\end{array}$ & 3.36 & Memory1 & 3.53 \\
\hline Memory3 & $\begin{array}{l}\text { I remember new grammar rules or structures by } \\
\text { remembering their location on the page, on the } \\
\text { board, or on a street sign. }\end{array}$ & 3.18 & Memory2 & 3.5 \\
\hline Memory1 & $\begin{array}{l}\text { I think of relationships between the grammar rules } \\
\text { or structures that I have already known and the new } \\
\text { ones I just learn. }\end{array}$ & 2.82 & Memory4 & 3.5 \\
\hline Memory4 & $\begin{array}{l}\text { I remember a new grammar rule or a structure by } \\
\text { making mental picture of a situation in which the } \\
\text { rule or the structure might be used. }\end{array}$ & 2.36 & Memory5 & 3.25 \\
\hline Memory2 & $\begin{array}{l}\text { I write sentences with new grammar rules or } \\
\text { structures so I can remember them easily. }\end{array}$ & 2.27 & Memory3 & 3.17 \\
\hline
\end{tabular}


Table 5. Memory strategies - Chinese low achievers vs. Thai low achievers

\begin{tabular}{|c|c|c|c|c|}
\hline \multirow{2}{*}{$\begin{array}{l}\text { Order of } \\
\text { strategies }\end{array}$} & \multirow[b]{2}{*}{ Description } & $\begin{array}{l}\text { Low } \\
\text { Chinese }\end{array}$ & \multirow{2}{*}{$\begin{array}{l}\text { Order of } \\
\text { strategies }\end{array}$} & \multirow{2}{*}{$\begin{array}{l}\text { Low } \\
\text { Thais } \\
\text { Means }\end{array}$} \\
\hline & & Means & & \\
\hline Memory3 & $\begin{array}{l}\text { I remember new grammar rules or structures by } \\
\text { remembering their location on the page, on the } \\
\text { board, or on a street sign. }\end{array}$ & 2.84 & Memory1 & 3.17 \\
\hline Memory5 & $\begin{array}{l}\text { I review the grammar rules and structures very } \\
\text { often. }\end{array}$ & 2.47 & Memory3 & 3.17 \\
\hline Memory1 & $\begin{array}{l}\text { I think of relationships between the grammar rules } \\
\text { or structures that I have already known and the new } \\
\text { ones I just learn. }\end{array}$ & 2.45 & Memory4 & 2.92 \\
\hline Memory4 & $\begin{array}{l}\text { I remember a new grammar rule or a structure by } \\
\text { making mental picture of a situation in which the } \\
\text { rule or the structure might be used. }\end{array}$ & 2.45 & Memory2 & 2.75 \\
\hline Memory2 & $\begin{array}{l}\text { I write sentences with new grammar rules or } \\
\text { structures so I can remember them easily. }\end{array}$ & 2.37 & Memory5 & 2.67 \\
\hline
\end{tabular}

Therefore, the means ranking comparison further revealed that the Thais and the Chinese had different preferences of the memory strategies. The former preferred the technique of mind mapping; the latter preferred the revision technique.

The independent sample T-test showed that the metacognitive strategy category was a strong feature that differentiated the lower Thais from the lower Chinese. A further comparison of the difference of the means of the metacognitive sub-strategies revealed an interesting cultural diversion. From Figure 12 and Figure 13, it can be seen that both the higher and lower Thais applied the metacognitive sub-strategy \#17 (learning grammar rules through the receptive skills) at a much greater frequency than the Chinese. On the other hand, both the higher and lower Chinese applied only 1 metacognitive sub-strategy, \#15 (lesson preview), at a higher frequency than the Thais.

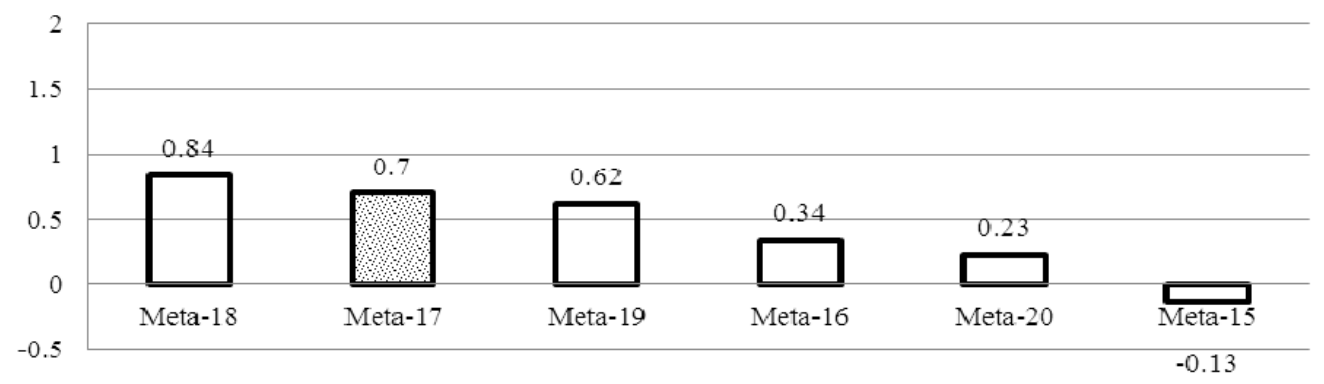

Figure 12. Means comparison of metacognitive sub-strategies - Higher Thais vs. Chinese

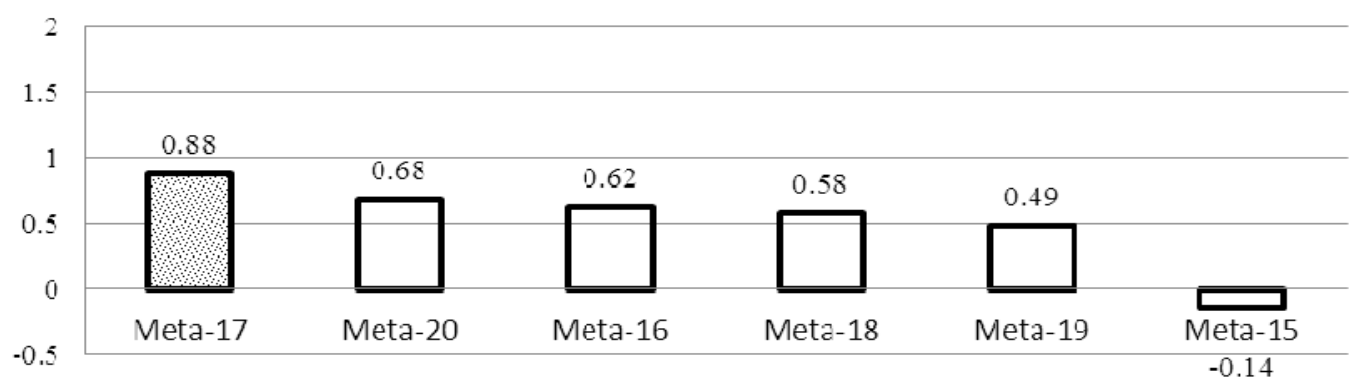

Figure 13. Means comparison of metacognitive sub-strategies - Lower Thais vs. Chinese 
Therefore, we can say that in general the Thais were better users of the metacognitive strategy category. However, the comparison of the metacognitive sub-strategies revealed that the Thais and the Chinese had different metacognitive preferences. The former preferred to learn new grammar rules through the receptive skills of listening and reading; the latter relied more on the lesson preview than the Thais.

\section{Conclusion}

\subsection{Major findings}

This study investigated English grammar learning strategies employed by both high and low achievement high school students and compared the grammar learning strategies applied by the Chinese and the Thais.

The results showed that of all the six strategy categories, those that best distinguished the higher achievers from the lower achievers were the following four: the metacognitive, the memory, the social, and the cognitive strategy categories.

Meanwhile, the national comparison of the Chinese and the Thais showed that the two strategy categories that strongly distinguished the Thais from the Chinese in this study were the social and the affective strategy categories. Specifically, regarding the application of the social strategies, the Thais relied highly on teachers and better learners for grammar learning methods. Moreover, in terms of the application of the affective strategies, the Thais also were highly better than the Chinese in terms of self-encouragement and relaxation.

A further comparison of the sub-strategies of the other two strategy categories that significantly differentiated the higher Thais from the higher Chinese - the cognitive and the memory - also revealed some interesting cultural variations. In terms of the cognitive strategies, while the Thais preferred to use tables to learn new grammar rules, the Chinese preferred note taking. Concerning the memory strategies, while the Thais relied on mental images to retain their grammar knowledge, the Chinese depended more on the revision.

Finally, a comparison of the sub-strategies of the other category that significantly differentiated the lower Thais from the lower Chinese - the metacognitive - showed that while the Thais made a highly more frequent access to the receptive skills to learn new grammar rules, the Chinese made more effort on the lesson preview.

\subsection{Implications}

The implications from this study are threefold: grammar learning strategies recommendations, suggestions for future research and a context sensitive insight for the grammar instruction.

Based on the results of this study, English learners of grammar may consider developing the four grammar learning strategies applied by the higher achievers in this study: the metacognitive, the memory, the social and the cognitive. In terms of the metacognitive strategies, the Thai higher achievers in this study reinforced their knowledge of the grammar rules through both the receptive and the productive skills; moreover, they also monitored their mistakes. In addition, because part of the learning of grammar involves the ability to remember rules, learners should also develop the memory strategies; suggested memory strategies by higher achievers from this study include the mind-mapping and the mental image techniques. A suggested social strategy to improve the grammar knowledge is learning how to learn grammar from teachers and better learners. To promote the grammar knowledge through the cognitive strategies, learners may try to understand English grammar through the comparison with L1 and summarize the acquired grammar knowledge in tables or diagrams.

The results from this study suggest an area for future research which should investigate whether the inclusion of learning activities that enhance learners' metacognition, memory, social engagement and cognition will help improve learners' grammar knowledge. Moreover, future studies on the comparison of achievement among grammar learners in four groups of different treatments of the grammar-learning strategies applied by the higher achievers in this study (metacognitive, memory, social and cognitive) are also interesting.

Moreover, Oxford (1996: xi) believes cultural background affects strategy choice. Similarly, Tomlinson (2005: 138) states, cultural norms can determine learning behavior. A concrete example was provided by Gao's study of 14 Chinese learners of English (2005), which reported that popular language learning discourses, assessment methods, and influential agents (including teachers, experts, friends, and family members) had an influence on the learners' frequency and choice of strategy use in China; moreover, strategy patterns changed when the learners moved to England. Gao further elaborated that some learners stopped their uses of memorizing, note taking, and regular reviewing strategies to retain new words; instead they relied on using more social strategies to guess, acquire and apply meanings of new words in actual conversations. In this regard, a number of scholars currently agree that cultural contexts are an important factor for the design of language education (Coleman, 1996; Duquette, 1995, Holliday, 1994; Stubbs, 2000; Padwad, 2002). McKay (1992: 47), for example, believes 
classrooms operate within a cultural context which to a large extent determines not only what is to be learned, but also how it is to be learned. Moreover, many scholars also propose that part of what to be learned in a language classroom should include learner-strategy training which must also take into account learners' cultural background (Rees-Miller, 1993, 1994; Chamot \& Rubin, 1994). This study provides a useful insight for teachers of English as a foreign language; grammar-learning activities should also properly address to learners' preferred strategies in different cultures. For example, to teach grammar to Thai students, who, based on the results of the study, tend to learn better through activities that include visual, auditory and social tasks. On the other hand, the Chinese, relatively more analytically inclined learners, seem to prefer learning through solitary activities: lesson preview, note taking and revision.

\section{Reference}

Anderson, N. J. (2005). L2 learning strategies. In E. Hinkel (Ed.), Handbook of research in second language teaching and learning (pp. 757-771). Mahwah, NJ: Lawrence Erlbaum.

Anderson, N. J. (2008). Metacognition and good language learners. In C. Griffiths (Ed.), Lessons from good language learners (pp. 99-109). Cambridge: Cambridge University Press. https://doi.org/10.1017/CBO9780511497667.010

Bade, M. (2008). Grammar and good language learners. In C. Griffiths (Ed.), Lessons from good language learners_(pp. 174-184). Cambridge University Press. https://doi.org/10.1017/CBO9780511497667.016

Batstone, R. (1994). Grammar. Oxford: Oxford University Press.

Bayou, Y, (2015). Grammar Learning Strategies Use of Grade 11 Students at Medhanealem Preparatory School: Gender in Focus (Unpublished master's thesis). Addis Ababa University, Addis Ababa, Ethiopia.

Chamot, A. U. (2004). Issues in language learning strategy research and teaching. Electronic Journal of Forieng Language Teaching, 1, 12-25

Chamot, A. U. (2008). Strategy instruction and good language learners. In C. Griffiths (Ed.), Lessons from good language learners (pp. 266-281). Cambridge: Cambridge University Press. https://doi.org/10.1017/CBO9780511497667.024

Chamot, A. U., \& Rubing, J. (1994). Comments on Janie Rees-Miller's “A critical appraisal of learner training: Theoretical bases and teaching implications." TESOL Quarterly, 28, 771-776. https://doi.org/10.2307/3587559

Chan, A. Y. W. (2005). Tactics employed and problems encountered by university English majors in Hong Kong in using a dictionary. Applied Language Learning, 15(1 \& 2), 1-27.

Cohen, A. D. (1998). Strategies in learning and using a second language. New York: Longman.

Cohen, A. D. (2008). Teaching and assessing L2 pragmatics: What can we expect from learners? Language Teaching, 4l(2), 215-237. https://doi.org/10.1017/S0261444807004880

Cohen, A. D. (2011). Second language learner strategies. In Eli Hikel (Ed.), Handbook of Research in Second Language Teaching and Learning Volume II (pp. 681-698). New York, NY: Routledge.

Cohen, A. D., Pinilla-Herrera, A., Thompson, J. R., \& Witzig, L. E. (2011). Communicating grammatically: Evaluating a learner strategies website for Spanish grammar. CALICO Journal, 29(1), 145-172. https://doi.org/10.11139/cj.29.1.145-172

Cohen, A. D., Weaver, S. J., \& Li, T. Y. (1997). The impact of strategies-based instruction on speaking a foreign language. Minneapolis, MN: Center for Advanced Research on Language Acquisition (CARLA), University of Minnesota.

Coleman, H. (1996). Society and the language classroom. Cambridge, UK: Cambridge University Press.

Dörnyei, Z., \& Skehan, P. (2003). Individual Difference in Second Language Learning. In C. J. Doughty, \& M. H. Long (Eds.), The Handbook of Second Language Acquisition (pp. 589-630). Malden, MA: Blackwell. https://doi.org/10.1002/9780470756492.ch18

Duquette, G. (1995). Second language practice. Clevedon, UK: Miltilingual Matters.

Duso, E. M. (2007). Dalla teoria alla pratica: la grammatica nella classe di italiano L2. Roma: ARACNE editrice.

Ehrman, M. E., Leaver, B. L., \& Oxford, R. L. (2003). A Brief Overview of Individual Differences in Second Language Learning. System, 31, 313-30. https://doi.org/10.1016/S0346-251X(03)00045-9 
Ellis, R. (2002). Methodological options in grammar teaching materials. In E. Hinkel, \& S. Fotos (Eds.), New perspectives on grammar teaching in second language classrooms (pp. 155-179). Mahwah, NJ: Lawrence Erlbaum Associates.

Ellis, R. (2004). Individual Differences in Second Language Learning. In A. Davies, \& C. Elder (Eds.), The handbook of Applied Linguistics (pp. 525-51). Malden, MA: Blackwell. https://doi.org/10.1002/9780470757000.ch21

Farjami, H. (2011). The effect of academic study on grammar attitude, grammar motivation and perception of grammar relevance. Modern Journal of Language Teaching Methods, 1(2), 68-81.

Fortune, A. (1992). Self-study grammar practice: Learners' views and preferences. ELT Journal, 46, $160-171$. https://doi.org/10.1093/elt/46.2.160

Gao, X. (2005). Understanding changes in Chinese students' uses of learning strategies in China and Britain: A socio-cultural re-interpretation. System, 34 (1), 55-67.

Goh, C. (1997). Metacognitive awareness and second language listeners. ELT Journal, 51, $361-369$. https://doi.org/10.1093/elt/51.4.361

Griffiths, C. (2010). Strategies of Successful Language Learners. Journal of English Language Studies, 1(3), $1-18$.

Harris, V., \& Grenfell, M. (2008). Learning to learn languages: The differential response of learners to strategy instruction. Unpublished manuscript, London: Department of Educational Studies, University of London.

Holliday, A. (1994). Appropriate methodology and social context. Cambridge, UK: Cambridge University Press.

Huang, P.-C. (2007). A metacognitive approach to the task demands encountered in business English writing. In Y. Leung, H. Chang, K. Cheung, \& W. Dai (Eds.), Selected papers from the 16th International Symposium and Book Fiar on English Teaching (pp. 255-265). Taipei: English Teachers' Association - Republic of China.

Iwai, C. (2006). Linguistic and pedagogical values of teaching communication strategies: Integrating the notion of communication strategies with studies of second language acquisition. Hiroshima: Hiroshima City University.

Larsen-Freeman, D. (2001). Teaching grammar. In M. Celce-Murcia (Ed.), Teaching English as a second or foreign language (pp. 251-266). Boston: Heinle \& Heinle.

Larsen-Freeman, D. (2003). Teaching language: From grammar to grammaring. Boston: Heinle \& Heinle.

Lightbown, P., \& Spada, N. (1999). How languages are learned (2nd ed.). New York: Oxford University Press.

McDonough, J. (2002). The teacher as language learner: Worlds of difference? ELT Journal, 56(4), 404-411. https://doi.org/10.1093/elt/56.4.404

McKay, S. (1992). Teaching English overseas. Oxford, UK: Oxford University Press. https://doi.org/10.1093/elt/46.2.199

Morales, M., \& Smith, D. J. (2008a). Spanish learning strategies of some good language learners. Porta Linguarum, 9, 167-177.

Morales, M., \& Smith, D. J. (2008b). Las imágenes mentales en la adquisición de la gramática de la segunda lengua: El caso de "ser" y "estar" en español (Mental images in the acquisition of L2 grammar: the case of ser and estar in Spanish). Revista nebrija de Lingüistica Aplicada a la Enseñanza de Lenguas, 2(3), 1-24.

Mystkowska-Wiertelak, A. (2008). The use of grammar learning strategies among secondary school students. In M. Pawlak, (Ed.) Investigating Language Learning and Teaching (pp. 139-148). Pozna-Kalisz: Adam Mickiewicz University Press.

Nunan, D. (1996). Learner strategy training in the classroom: An action research study. TESOL Journal, 6(1), $35-41$.

O’Malley, J. M., \& Chamot, A. U. (1990). Learning strategies in second language acquisition. New York: Cambrige University Press. https://doi.org/10.1017/CBO9781139524490

Oxford, R. L. (1990). Language learning strategies: what every teacher should know. Boston: Heinle \& Heinle.

Oxford, R. L. (Ed.). (1996). Language learning strategies around the world: Cross-cultural perspectives. Manoa: University of Hawaii Press. 
Oxford, R. L. (2001). Language learning strategies. In R. Carter, \& D. Nunan (Eds.), The Cambridge guide to teaching English to speakers of other languages (pp. 166-172). Cambridge: Cambridge University Press. https://doi.org/10.1017/CBO9780511667206.025

Oxford, R. L., \& Leaver, B. L. (1996). A synthesis of strategy instruction for language learners. In R. L. Oxford (Ed.), Language learning strategies around the world: Crosscultural perspectives (pp. 227-246). National Foreign Language Resource Center. Manoa: University of Hawaii Press.

Oxford, R. L., Lee, K. R., \& Park, G. (2007). L2 grammar strategies: the Second Cinderella and beyond. In A. D. Cohen, \& E. Macaro (Eds.), Oxford Applied Linguistics: Language Learner Strategies (pp. 117-139). Oxford: Oxford University Press.

Padwad, A. (2002). Review of teaching and learning in the language classroom. The English Teacher: An International Journal, 5(2), 191-193.

Pawlak, M. (2008). Advanced learners' use of strategies for learning grammar: A diary study. In M. Pawlak (Ed.) Investigating English language learning and teaching (pp.109-125). Poznań- Kalisz: Adam Mickiewicz University Press.

Pawlak, M. (2009). Grammar learning strategies and language attainment: Seeking a relationship. Research in Language, 7, 43-60. https://doi.org/10.2478/v10015-009-0004-7

Pontarolo, Giulia (2013) The role of grammar in EFL instruction: a study on secondary school students and teachers. (Unpublished doctoral dissertation). Università degli Studi di Padova, Padua, Italy.

Purpura, J. E. (2004) Assessing grammar. Cambridge: Cambridge University Press. https://doi.org/10.1017/CBO9780511733086

Rees-Miller, J. (1993). A critical appraisal of learner training: Theoretical bases and teaching implications. TESOL Quarterly, 27, 679-689. https://doi.org/10.2307/3587401

Rees-Miller, J. (1994). The author responds. TESOL Quarterly, 28, 776-781. https://doi.org/10.2307/3587560

Robinson, P. (2002). Individual Differences and Instructed Language Learning. John Benjamins, Amsterdam. https://doi.org/10.1075/11lt.2

Rubin, J. (1975). What the "Good Language Learner" Can Teach Us. TESOL Quarterly, 9(1), 41-51. https://doi.org/10.2307/3586011

Rubin, J., Chamot, A. U., Harris, V., \& Anderson, N. J. (2007). Intervening in the use of strategies. In A.D. Cohen, \& E. Macaro (Eds.), Language learner strategies: 30 years of research and practice (pp. 141-160). Oxford: Oxford University Press.

Saaristo, P. (2015). Grammar is the heart of language: grammar and its role in language learning among Finnish university students. In J. Jalkanen, E. Jokinen, \& P. Taalas (Eds.), Voices of pedagogical development Expanding, enhancing and exploring higher education language learning (pp. 279-318). Dublin: Research publishing. http://doi:10.14705/rpnet.2015.000296

Sharwood Smith, M. (1993). Input enhancement in instructed SLA. Studies in Second Language Acquisition, 15, 165-179. https://doi.org/10.1017/S0272263100011943

Skehan, P. (1989). Individual differences in second language learning. London: Arnold.

Sykes, J. M., \& Cohen, A. D. (2008). Observed learner behavior, reported use, and evaluation of a website for learning Spanish pragmatics. In M. Bowles, R. Foote, \& S. Perpiñán (Eds.), Second language acquisition and research: Focus on form and function. Selected Proceedings of the 2007 Second Language Research Forum (pp. 144-157). Somerville, MA: Cascadilla Press.

Sykes, J. M., \& Cohen, A. D. (2009). Learner perception and strategies for pragmatic acquisition: A glimpse into online learning materials. In C. R. Dreyer (Ed.), Language and Linguistic: Emerging trends (pp. 99-135). Hauppauge, NY: Nova Science Publishers.

Stubbs, M. (2000). Society, education and language: The last 2,000 (and the next 20?) years of language teaching. In H. Trappes-Lomax (Ed.), Change and continuity in applied linguistics (pp. 15-37). Clevedon, UK: British Association of Applied Linguistics/Multilingual Matters.

Sun, M., Mantero, M., \& Summers, R. (2014). Chinese Adult Second Language Learners' Learning Strategy and Communicative Strategy Use. Journal of Second and Multiple Language Acquisition - JSMULA, 2(1), 22-35. 
Tilfarlioğlu, Y. (2005). An Analysis of the relationship between the use of grammar learning strategies and student achievement at English preparatory classes. Journal of Language and Linguistic Studies 1, 155-169.

Tomlinson, B. (2005). English as a foreign language: Matching procedure to the context of learning. In E. Hinkel (Ed.), Handbook of research in second language teaching and learning (pp. 137-153). Mahwah, NJ: Lawrence Erlbaum.

Vance, S. J. (1999). Language learning strategies: Is there a best way to teach them? Unpublished manuscript. ERIC Institute of Education Sciences. Retrieved from https://files.eric.ed.gov/fulltext/ED438716.pdf

Vandergrift, L. (1997). The strategies of second language (French) listeners: A descriptive study. Foreign Language Annals, 30, 387-409. https://doi.org/10.1111/j.1944-9720.1997.tb02362.x

Vandergrift, L. (1999). Facilitating second language listening comprehension: Acquiring successful strategies. ELT Journal, 53, 168-176. https://doi.org/10.1093/elt/53.3.168

Vandergrift, L. (2002). It was nice to see that our predictions were right: Developing metacognition in L2 listening comprehension. The Canadian Modern Language Review, 58, 555-575. https://doi.org/10.3138/cmlr.58.4.555

Vann, R. J., \& Abraham, R. G. (1990). Strategies of unsuccessful language learners. TESOL Quarterly, 24, 177-198. https://doi.org/10.2307/3586898

Wang, F. J. (2010). The Necessity of Grammar Teaching. English Language Teaching, 3(2), 78-81. https://doi.org/10.5539/elt.v3n2p78

Wenden, A. L. (1998). Metacognitive knowledge and language learning. Applied Linguistics, 19, 515-537. https://doi.org/10.1093/applin/19.4.515

Zhang, L. J. (2008). Constructivist pedagogy in strategic reading instruction: Exploring pathways to learner development in the English as a second language (ESL) classroom. Instructional Science, 36(2), 89-116. https://doi.org/10.1007/s11251-007-9025-6

\section{Copyrights}

Copyright for this article is retained by the author(s), with first publication rights granted to the journal.

This is an open-access article distributed under the terms and conditions of the Creative Commons Attribution license (http://creativecommons.org/licenses/by/4.0/). 